\title{
Stock Market Reforms and Stock Market Performance
}

\author{
Karthigai Prakasam Chellaswamy ${ }^{1}$, Natchimuthu $\mathrm{N}^{1}$ \& Muhammadriyaj Faniband ${ }^{1}$ \\ ${ }^{1}$ Department of Commerce, CHRIST (Deemed to be University), Bengaluru, India \\ Correspondence: Karthigai Prakasam Chellaswamy, Department of Commerce, CHRIST (Deemed to be University), \\ Bengaluru, India.
}

Received: August 16, 2020

Accepted: October 12, 2020

Online Published: January 14, 2021

doi:10.5430/ijfr.v12n2p202

URL: https://doi.org/10.5430/ijfr.v12n2p202

\begin{abstract}
This paper analyses the impact of stock market reforms on the stock market performance in India using regression based event-study method. We consider nine stock market reforms introduced from 1998 to 2018 . We find that the impact of stock market reforms on Nifty trading volume and Nifty return is different. This paper documents that the impact of the additional volatility measures, $\mathrm{T}+3$ and $\mathrm{T}+2$ settlement cycles, and margin provisions for intra-day crystallized losses reforms show a positive impact on trading volume post-reform. In contrast, internet trading, prohibition of fraudulent and unfair trade practices, delisting of equity shares, substantial acquisition of shares and takeovers listing obligations and disclosure requirements reforms decrease the trading volume post-reform. Our results of Nifty return reveal that the additional volatility measures, the $\mathrm{T}+2$ settlement cycle, the prohibition of fraudulent and unfair trade practices, substantial acquisition of shares and takeovers, listing obligations and disclosure requirements have a significant and positive impact on return post-reform. It is evident that the impact of all nine stock market reforms is insignificant on Nifty return.
\end{abstract}

Keywords: stock market reforms, stock market performance, event study, regression, nifty, trading volume, return, India

\section{Introduction}

The Government of India has taken adequate steps after independence to ensure the organized growth of the economy. Since India opened its economy in 1991, the Indian government has employed various policies to reform and enhance its underdeveloped stock market. The reforms in the Indian stock market began in the late 1980s with the formation of the Securities and Exchange Board of India (SEBI), but it derived substantial impulse with the consolidation of all regulatory authority with SEBI in 1992. Since then numerous reforms have been executed. In this context, it becomes imperative to evaluate the impact of such broad reforms on the performance of stock market in India.

In this paper, we attempt to examine the impact of nine stock market reforms introduced in India from 1998 to 2018 on stock market performance using the regression based event-study method. The stock market reforms considered for this study are Additional Volatility Measures (AVM), internet trading, $\mathrm{T}+3$ settlement cycle, $\mathrm{T}+2$ settlement cycle, prohibition of fraudulent and unfair trade practices, delisting of equity shares, substantial acquisition of shares and takeovers, listing obligations and disclosure requirements and margin provisions for intra-day crystallized losses. This paper focuses on the stock market reforms in India because of its increasing importance at the global platform and changing regulatory environment. India's stock market presents a unique market structure with two national exchanges, Bombay Stock Exchange and National Stock Exchange (NSE). The NIFTY is a benchmark index that represents the weighted average of 50 of the largest Indian companies listed in the NSE. NSE is the leading stock exchange in India and the second largest in the world by numbers of trades in equity shares from January to June 2018, according to the World Federation of Exchanges report. We also take into account trading volume because it reflects the strength of the market. It is important to look at the relationship between stock market reforms and trading volume. Therefore, an analysis of stock market reforms and trading volume allows the investor to better interpret the market trends with the changes in the stock market. Therefore, we choose Nifty trading volume and Nifty returns as dependent variables.

This paper addresses two unanswered questions. 1) Do stock market reforms impact the Nifty trading volume? 2) Do stock market reforms have a similar impact on Nifty return? 
This paper contributes to the existing literature in two ways. First, this paper represents the first attempt to study the effects of stock market reforms on stock market performance in India to the best of our knowledge. Second, earlier studies highlight the stock market reforms in India. This paper aims to extend this research to evaluate how such stock market reforms affect stock market performance.

We find mixed impact of India's stock market reforms on Nifty trading volume and return. The impact of four stock market reforms is positive on trading volume, whereas the impact of all nine stock market reforms is insignificant on return.

This paper is organized as follows. Section 2 discusses the major stock market reforms in India. Section 3 presents related studies. Section 4 indicates data and methodology. Section 5 illustrates the empirical results and finally section 6 shows the conclusion and implications.

\section{The Major Stock Market Reforms in India}

Like many developing countries, the Indian government also attempted to liberalise India's stock market. The stock market reforms introduced in India have helped Indian stock market to become more congruent with the developed markets. In this section, the following select nine stock market reforms introduced during 1998 to 2018 are discussed.

SEBI prescribed AVM to curb volatility in share price on 6 July 1998. It includes; (1) the daily price band was reduced from $10 \%$ to $8 \%$. (2) The weekly price band of $25 \%$ was removed and a graded margin was prescribed.

Internet Based Trading and Services was approved on 31 January 2000 by SEBI. Internet trading takes place through order routing systems, which routes client orders to exchange trading systems for execution.

India's trading settlement cycles have experienced various changes. On 1 April 2002, the settlement cycle for all securities was shortened to the $\mathrm{T}+3$ bases from $\mathrm{T}+5$. With this reform, the Indian securities market complied with the standard of the Bank for International Settlements and the International Organization of Securities Commissions. Further, the settlement cycle has been shortened from the $T+3$ rolling settlement to $T+2$ by SEBI to facilitate still easier flow of funds and securities on 1 April 2003.

On 17 July 2003, the 'Prohibition of Fraudulent and Unfair Trade Practices relating to Securities Market' regulation has been made by SEBI. This regulation includes three chapters. Chapter I - Preliminary, Chapter II - Prohibition of Fraudulent and Unfair Trade Practices Relating to the Securities Market and Chapter III - Investigation. On 10 June 2009, the 'Delisting of Equity Shares' regulation has been made. This Regulation Contains Eight Chapters. Chapter I - Preliminary, Chapter II - Delisting Of Equity Shares, Chapter III - Voluntary Delisting, Chapter IV - Exit Opportunity, Chapter V - Compulsory Delisting, Chapter VI - Powers Of the Board and Chapter VII - Special Provisions for Small Companies and Delisting by Operation of Law.

The Substantial Acquisition of Shares and Takeovers reform was made on 23 September 2011. This reform is about discloser of an acquirer's aggregate shareholding to the target company, an open offer by acquirer, the creeping limit of 5 percent and consolidation of holding. The 'Listing Obligations and Disclosure Requirements' regulation was introduced on 2 September 2015. The regulation on 'Margin provisions for intra-day crystallized losses' has been made on 8 January 2018.

\section{Related Research}

In this section, the review of previous studies conducted in emerging and developed economies on stock market reforms and its impact on stock market is carried out. This section also covers the impact of other related issues on stock market. Weston, (2000) examine the effect of market reforms on the competitive structure of the National Association of Securities Dealers Automated Quotations (NASDAQ). The post-reform decrease in bid-ask spreads is not explained by changes in inventory and information costs. NASDAQ dealers' rents are reduced due to the reforms. The difference between NASDAQ and NYSE spreads was greatly diminished with the new rules. Ngugi, Murinde, \& Green (2003) analyse the effects of the revitalization of the regulatory framework, modernization of trading systems, and relaxation of restrictions on foreign investors on ten stock exchanges in Africa. Their study finds that markets with advanced trading technology, tight regulatory system and relaxed foreign investors' participation have indicated greater efficiency and lower market volatility. Ojo and Adeusi (2012) note the positive impact of capital reforms on Nigerian economic growth. Ignacio Pena (1995) study the effects of the Spanish Stock Exchange reform on the seasonal patterns of daily stock excess returns. The market's operational efficiency increased because daily seasonal effects disappeared after the reform.

A substantial amount of research is conducted on the effects of China's stock market reforms on various segments. 
$\mathrm{Li}$ (2012) investigates the impact of China's stock market reforms on the stock market linkages between China and Korea, Japan, and the US respectively using a $4 \times 4$ asymmetric GARCH-BEKK model and a series of likelihood ratio tests to uncover China's regional and global linkages. The linkages were found between the Chinese stock market and these overseas markets and the reforms permitted spillovers to these markets from China. Lin and Swanson (2008) finds that China's security law implementation has strengthened return relationships within its two domestic exchanges and volatility is transmitted between China's stock markets and world markets due to market liberalization from opening its A-share markets to foreign investors. Chen, Blenman, \& Bin (2011) reveal the positive impact of the new policy of allowing local residents to invest in Class B in China on the Class B share price and reduced price volatility. Flora (2012) analyse the reforms in the Chinese stock market and how future Chinese capital markets are affected due to such changes. The paper covered the new initiatives to attract Chinese technology companies to list or relist domestically, as well as the internationalization of Chinese capital markets and the recent Initial Public Offering (IPO) reform. Su and Brookfield (2013) examine the impact of stock market reforms in China on the certification role of underwriters in reducing substantial IPO underpricing.

In the Indian context, Gokarn (1996) assess capital market reforms during 1992-96. Ahluwalia (2002) takes an overview of economic reforms including the stock market. Goswami (2003) study working of internet trading and suggested to lower the cost of transactions, improve customer data, increase cost-selling opportunities and integrate new financial products.

The relationship between the stock market and economic growth is also covered in previous research literature. Osaseri and Osamwonyi (2019) find a positive correlation between stock market development indicators and economic growth of Brazil, Russia, India, China and South Africa. David and Department (2017) study the impact of stock market reforms on capital formation in Nigeria and note the positive influence of the prosperity in the stock market on gross capital formation. Jalloh (2014) assess the influence of financial reforms in West Africa on economic growth.

The literature on trading volume or trading activity in financial markets is encompassing and several studies on trading volume have been proposed (see Chari, Panda, \& Korivi 2017; Kambeu, 2019; Lee \& Rui, 2002; Lo \& Wang, 2000; Mulherin, 1990; Wang, Qian, \& Wang, 2018). Jha, Bhattacharya, and Bhattacharya (2019) find that a surge in Google search queries is linked to an increase in trading activity and stock liquidity in NSE. In other context, a recent study by Misman, Roslan, and Aladin (2020) state that the 14th general election in Malaysia has a significant impact on the stock market performance.

Several research finds the impact of company-specific factors on stock prices (see Faniband and Marulkar, 2020; Syed and Bajwa, 2018; Sharma, Mahendru, and Singh 2015). Many studies have confirmed the effect of macro and non-macroeconomic factors on the stock market (see Aggarwal, 2017; Chellaswamy, Natchimuthu, and Faniband, 2020; Panwar and Nidugala, 2019; Rehman, Mahdzan, and Zainudin, 2016; Faniband and Prakasam, 2019; Sabri, 2009; Sengupta, Dutta, \& Dutta, 2019).

Previous studies have overviewed the stock market reforms. The impact of such reforms on stock market performance has been studied in developed and emerging markets. However, the impact of stock market reforms on stock market performance in India has not been analysed. Further, the earlier studies have not focused on the impact of stock market reforms on trading volume. These issues were ignored in the past studies. Therefore, we fill this gap in this paper and extend the literature.

\section{Data and Methodology}

In this paper, we consider nine stock market reforms introduced in India from 1998 to 2018. This paper tests the effects of stock market reforms on Nifty trading volume and return. This paper takes the log return of nifty close prices. The original data of Nifty trading volume and close prices are extracted from the website of Yahoo Finance.

To study the impact of stock market reforms, the dataset is divided into two parts, pre-reform and post-reform. This paper analyses the impact of stock market reforms on trading volume one month (30 days) before the date of reform and trading volume one month after the date of reform. Similarly, we also examine the effects of stock market reform on Nifty return one month before the date of the reform and Nifty return one month after the date of the reform.

The stationarity of return and trading volume series is tested using the Augmented Dickey-Fuller (ADF) test. We also use the serial correlation test to test the existence of auto correlation. Additionally the Breusch-Pagan-Godfrey test is employed to detect heteroscedasticity in the model.

We use regression based event-study method to study the impact of stock market reforms on Nifty trading volume and Nifty return. Despite the fact that this method has a couple of limitations but it is the most pertinent and 
dependable technique to study the effects of change in any policy on the concerning factor. This method is also advocated by (Bernanke and Kuttner, 2005; Hansen and Tarp, 2001; Khuntia and Hiremath, 2019). In order to observe the reform effect, we estimate nine regression models using a time dummy variable. To remove the problem of autocorrelation, Autoregressive (AR) order one process is added in the regression model.

The regression model expressed as:

$$
\begin{aligned}
& R_{l}=\alpha+\beta_{1} P R_{t}+e_{t} \\
& R_{2}=\alpha+\beta_{I} P R_{t}+e_{t} \\
& R_{3}=\alpha+\beta_{1} P R_{t}+e_{t} \\
& R_{4}=\alpha+\beta_{1} P R_{t}+e_{t} \\
& R_{5}=\alpha+\beta_{1} P R_{t}+e_{t} \\
& R_{6}=\alpha+\beta_{1} P R_{t}+e_{t} \\
& R_{7}=\alpha+\beta_{1} P R_{t}+e_{t} \\
& R_{8}=\alpha+\beta_{1} P R_{t}+e_{t} \\
& R_{9}=\alpha+\beta_{1} P R_{t}+e_{t}
\end{aligned}
$$

Where, $R$ represents trading volume/return for 60 trading days ( 30 days pre-reform and 30 days post-reform) for the select reform. $R_{I}$ shows AVM reform, $R_{2}$ indicates internet trading reform, $R_{3}$ is $\mathrm{T}+3$ settlement cycle reform, $R_{4}$ refers $\mathrm{T}+2$ settlement cycle, $R_{5}$ is the prohibition of fraudulent and unfair trade practices reform, $R_{6}$ is delisting of equity shares reform, $R_{7}$ shows the substantial acquisition of shares and takeovers reform, $R_{8}$ presents listing obligations and disclosure requirements reform and $R_{9}$ is margin provisions for intra-day crystallized losses reform. The term $P R_{t}$ is time dummy variable (it takes the value of one for post-reform and zero otherwise), whereas $e_{t}$ is the error term.

\section{Empirical Results}

This section is mainly divided into two sub-sections. The first sub-section summarizes the impact of stock market reform on Nifty volume and the second sub-section discusses the results of the impact of stock market reform on Nifty return.

Table 1. Unit root test

\begin{tabular}{lll}
\hline Reforms & Volume & Return \\
\hline Additional Volatility Measures & -1.663 & $-6.997^{* * *}$ \\
\hline Internet Trading & $-4.718^{* * *}$ & $-9.177^{* * *}$ \\
\hline $\mathrm{T}+3$ Settlement Cycle & $-4.117^{* *}$ & $-7.056^{* * * *}$ \\
\hline T+2 Settlement Cycle & $-3.434^{* *}$ & $-6.258^{* * *}$ \\
\hline Prohibition of Fraudulent and Unfair Trade Practices & -2.113 & $-5.935^{* * *}$ \\
\hline Delisting of Equity Shares & -2.832 & $-7.673^{* * *}$ \\
\hline Substantial Acquisition of Shares and Takeovers & $-5.852^{* * *}$ & $-7.121^{* * *}$ \\
\hline Listing Obligations and Disclosure Requirements & $-4.408^{* * *}$ & $-7.794^{* * *}$ \\
\cline { 2 - 4 } Margin provisions for intra-day crystallized losses $^{* *} \mathrm{p}<0.05$ and ${ }^{* * *} \mathrm{p}<0.01$ & $-3.217^{* *}$ & $-5.859^{* * *}$ \\
\hline
\end{tabular}

Each volume series is tested individually to ensure non-stationarity at the levels. The ADF test statistics given in Table 1 show that the AVM reform, prohibition of fraudulent and unfair trade practices reform and delisting of equity shares reform have a unit root. Therefore, these reforms are included in the first difference to make them stationary. However, the other Nifty trading volume series attain stationarity. On the other hand, all the return series found to be stationary. 


\subsection{Impact of Stock Market Reforms on Nifty Trading Volume}

Table 2. Estimation results for nifty trading volume

\begin{tabular}{llll}
\hline Reforms & Constant & Time Dummy & AR(1) \\
\hline Additional Volatility Measures & $492.610^{* * * *}$ & 55.715 & $0.861^{* * * *}$ \\
\hline Internet Trading & $991.850^{* * * *}$ & -77.689 & $0.408^{* * * *}$ \\
\hline $\mathrm{T}+3$ Settlement Cycle & $1305.843^{* * * *}$ & 70.586 & $0.515^{* * * *}$ \\
\hline $\mathrm{T}+2$ Settlement Cycle & $1386.820^{* * * *}$ & $259.783^{* * * *}$ & $0.532^{* * * *}$ \\
\hline Prohibition of Fraudulent and Unfair Trade Practices & $6755.398^{* * * *}$ & $-1331.128^{* * * *}$ & - \\
\hline Delisting of Equity Shares & $12070.930^{* * * *}$ & -2021.152 & $0.432^{* * * *}$ \\
\hline Substantial Acquisition of Shares and Takeovers & $6755.398^{* * * *}$ & $-1331.128^{* * * *}$ & - \\
\hline Listing Obligations and Disclosure Requirements & $9751.490^{* * * *}$ & -1170.813 & $0.401^{* * * *}$ \\
\hline Margin Provisions for Intra-Day Crystallized Losses & $15614.130^{* * *}$ & 973.766 & - \\
\hline
\end{tabular}

The results of the impact of stock market reforms on Nifty trading volume are presented in Table 2. The coefficient value of AVM reform is 55.715 which is insignificant to explain the effect of this reform on trading volume. However, the impact of this reform is positive on trading volume. Notably, the coefficients of internet trading reform were statistically insignificant and negative, suggesting that trading activity has decreased after this reform.

Implementing the $\mathrm{T}+3$ settlement cycle reform brings a positive change in trading volume as the coefficient value is positive for the $\mathrm{T}+3$ settlement cycle reform. However, the impact is statistically insignificant. In contrast, Nifty experiences increase in trading volume due to the introduction of $\mathrm{T}+2$ settlement cycle reform. This reform has a significant and positive effect on trading volume.

In the case of the prohibition of fraudulent and unfair trade practices reform, the effect is found to be significant and negative on trading volume. It is important to note an insignificant and negative impact of the delisting of equity shares. On the other hand, substantial acquisition of shares and takeovers reform has a significant and negative impact. The listing obligations and disclosure requirements reform could not influence the nifty volume and it has a negative impact. Further, we find no significant impact of the margin provisions for intra-day crystallized losses reform on trading volume. But this reform increases the trading volume post-reform as the coefficient value is positive.

In a nutshell, four stock market reforms increase the trading volume post-reform, whereas trading volume has gone down after the introduction of five reforms. Moreover, only three reforms significantly influence the trading volume post-reform.

The problem of auto correlation is found in six regression models, namely, AVM, internet trading, $t+3$ and $t+2$ settlement cycles, delisting of equity shares and listing obligations and disclosure requirements. Furthermore, the problem of heteroscedasticity is not found in any regression model.

\subsection{Impact of Stock Market Reforms on Nifty Return}

Table 3. Estimation results for nifty return

\begin{tabular}{llll}
\hline Reforms & Constant & $\begin{array}{l}\text { Time } \\
\text { Dummy }\end{array}$ & AR(1) \\
\hline Additional Volatility Measures & $-0.703^{* *}$ & 0.440 & $-0.303^{* *}$ \\
\hline Internet Trading & 1305.843 & -0.068 & - \\
\hline T+3 Settlement Cycle & 0.046 & -0.165 & - \\
\hline T+2 Settlement Cycle & -0.219 & 0.120 & - \\
\hline
\end{tabular}




\begin{tabular}{lllll}
\hline Prohibition of Fraudulent and Unfair Trade Practices & 0.450 & 0.088 & - \\
\hline Delisting of Equity Shares & 0.780 & -0.969 & - \\
\hline Substantial Acquisition of Shares and Takeovers & -0.267 & 0.212 & - \\
\hline Listing Obligations and Disclosure Requirements & -0.304 & 0.440 & - \\
\hline Margin Provisions for Intra-Day Crystallized Losses & 0.057 & -0.105 & - \\
\hline 0.05 and $^{* * *} \mathrm{p}<0.01$ & & &
\end{tabular}

Table 3 illustrates the estimation results for the impact of stock market reforms on Nifty return. Regarding AVM reform, the coefficient value is not significant to explain the nifty return. Since the coefficient is positive, there is an increase in return after this reform. Further, the effect of internet trading reform is insignificant and negative on returns.

Introducing a series of reforms in trading settlement cycle was crucial to comply with the International standard. The results of the $\mathrm{T}+3$ settlement cycle reforms show an insignificant and negative effect on returns. As expected, the $\mathrm{T}+2$ settlement cycle reform has a positive but insignificant effect.

The prohibition of fraudulent and unfair trade practices reform insignificantly affects the return. However, the return experiences a surge post-reform because the coefficient value of this reform is positive. Further, we find that the effect of the delisting of equity shares reform is insignificant and negative on return. However, we notice an insignificant and positive impact of substantial acquisition of shares and takeovers reform. The results of listing obligations and disclosure requirements reform are also in a similar line i.e. insignificant and positive. The margin provisions for intra-day crystallized losses reform are found to have an insignificant and negative impact on returns.

In short, five stock market reforms have a positive impact, while four reforms show a negative effect on return. It is also important to note an insignificant impact of all nine reforms on return.

We detect the problem of auto correlation in a regression model i.e. the AVM reform. But, there exists no autocorrelation in other regression models. Furthermore, the problem of heteroscedasticity is not found in any regression model.

\section{Conclusion and Implications}

Our results shed light on the effect of stock market reforms on Nifty trading volume and return. This paper has found that stock market reforms have had mixed effects on the stock market performance in India. Moreover, the stock market reforms have not affected trading volume and return in a similar way.

The estimation results of the impact of stock market reforms on trading volume indicate that the AVM, T+3 and T+2 settlement cycles and margin provisions for intra-day crystallized losses reforms have a positive impact on the trading volume whereas internet trading, prohibition of fraudulent and unfair trade practices, delisting of equity shares, substantial acquisition of shares and takeovers and listing obligations and disclosure requirements reforms decrease the trading volume meaning that these reforms have a negative impact.

Further, the results of the influence of stock market reforms on Nifty return reveal that AVM, T+2 settlement cycle, prohibition of fraudulent and unfair trade practices, substantial acquisition of shares and takeovers, listing obligations and disclosure requirements have a positive impact on return. On the other hand, the other reforms show a negative impact. In a nutshell, all nine stock market reforms have an insignificant impact on return.

This paper captures the stock market reforms in India and its impact on Nifty trading volume and return to give an insight to the stock market investors and the market analyst. In the future, if reforms are made in similar lines, they can understand the magnitude of such changes that reflects in trading volume and return and accordingly they can take positions in the investment front.

The major limitation of this paper is that the results of this research cannot be generalised to countries other than India. This paper is the first attempt to find the relationship between stock market reforms and stock market performance in India. However, further studies can be extended to know the impact of economic, financial and banking reforms on stock market performance. Another possible line of future research could be the impact of India's stock market reforms on the other emerging and developed countries' stock markets performance. 


\section{References}

Ahluwalia, M. S. (2002). Economic reforms in India since 1991: Has gradualism worked?. Journal of Economic Perspectives, 16(3), 67-88. https://doi.org/10.1257/089533002760278721

Bernanke, B. S., \& Kuttner, K. N. (2005). What explains the stock market's reaction to federal reserve policy?. Journal of Finance, 60(3), 1221-1257. https://doi.org/10.1111/j.1540-6261.2005.00760.x

Chari, L. S., Panda, P., \& Korivi, S. R. (2017). Impact of market-wide circuit-breaker on trading activity and volatility: Empirical evidence from Indian markets. Prajnan, 46(1), 37-53.

Chellaswamy, K. P., Natchimuthu, N., \& Faniband, M. (2020). Stock Market Sensitivity to Macroeconomic Factors: Evidence from China and India. Asian Economic and Financial Review, 10(2), 146-159. https://doi.org/10.18488/journal.aefr.2020.102.146.159

Chen, D., Blenman, L. P., \& Bin, F. (2011). The effects of open market reforms on the behavior of China's stock prices. Journal of Chinese Economics and Finance, 1(1), 39-53.

David, O. O. K., \& Department, A. S. O. (2017). Analysis of the impact of stock market reforms on capital formation in Nigeria (1986-2016): Ardl bound test error- correction model (Ardl-Ecm) approach. Research Journali's Journal of Economics, 5(1), 1-18.

Faniband, M. M., \& Marulkar, K. V. (2020). Quarterly results and share prices: What happens on the date of earnings announcement?. Finance India, 34(1), 153-162.

Faniband, M., \& Prakasam, C. K. (2019). Determinants of differential voting rights share prices and ordinary share prices: Evidence from Dual-Class companies in India. Indian Journal of Research in Capital Markets, 6(4), 36-49. https://doi.org/10.17010/ijrcm/2019/v6/i4/150270

Flora, H. (n.d.). The future of chinese capital markets (pp. 81-91). Retrieved from http://repository.essex.ac.uk/22038/1/FutureChineseMarkets.pdf

Gokarn, S. (1996). Indian capital market reforms, 1992-1996: An assessment. Economic and Political Weekly, $31(15), 956-961$.

Goswami, C. (2003). How does internet stock trading in India work?. Vikalpa, 28(1), 91-98. https://doi.org/10.1177/0256090920030108

Hansen, H., \& Tarp, F. (2001). Aid and growth regressions. Journal of Development Economics, 27, 547-570. https://doi.org/10.1016/S0304-3878(00)00150-4

Ignacio Pena, J. (1995). Daily seasonalities and stock market reforms in Spain. Applied Financial Economics, 5(6), 419-423. https://doi.org/10.1080/758538601

Jalloh, M. (2014). Financial sector reforms and economic growth: the West African experience. Afro-Asian Journal of Finance and Accounting, 4(2), 163-181. https://doi.org/10.1504/AAJFA.2014.063762

Jha, S. K., Bhattacharya, S. N., \& Bhattacharya, M. (2019). Google search volume and stock market liquidity. Indian Journal of Finance, 13(8), 51-64. https://doi.org/10.17010/ijf\%2F2019\%2Fv13i8\%2F146304

Kambeu, E. (2019). Trading Volume as a Predictor of Market Movement. International Journal of Finance \& Banking Studies, 8(2), 57-69. https://doi.org/10.20525/ijfbs.v8i2.177

Khuntia, S., \& Hiremath, G. S. (2019). Monetary policy announcements and stock returns: some further evidence from India. Journal of Quantitative Economics, 17(4), 801-827. https://doi.org/10.1007/s40953-019-00158-y

Lee, B. S., \& Rui, O. M. (2002). The dynamic relationship between stock returns and trading volume: Domestic and cross-country evidence. Journal of Banking and Finance, 26(1), 51-78. https://doi.org/10.1016/S0378-4266(00)00173-4

Li, H. (2012). The impact of China's stock market reforms on its international stock market linkages. Quarterly Review of Economics and Finance, 52(4), 358-368. https://doi.org/10.1016/j.qref.2012.10.003

Lin, A. Y., \& Swanson, P. E. (2008). The Effect of China 's reform policies on stock market information transmission. Quarterly Journal of Finance and Accounting, 47(3), 49-76.

Lo, A. W., \& Wang, J. (2000). Trading volume: Definitions, data analysis, and implications of portfolio theory. Review of Financial Studies, 13(2), 257-300. https://doi.org/10.1093/rfs/13.2.257

Misman, F. N., Roslan, S., \& Aladin, M. I. M. (2020). General election and stock market performance: A Malaysian 
case. International Journal of Financial Research, 11(3), 139-145. https://doi.org/10.5430/ijfr.v11n3p139

Mulherin, J. H. (1990). Trading volume and stock market volatility. Revue Économique, 41(5), 923-937.

Ngugi, R. W., Murinde, V., \& Green, C. J. (2003). How have the emerging stock exchanges in africa responded to market reforms?. Journal of African Business, 4(2), 89-127. https://doi.org/10.1300/j156v04n02_06

Ojo, O. M., \& Adeusi, S. (2012). Impact of capital market reforms on economic growth: The Nigerian experience. Australian Journal of Business and Management Research, 2(2), 20-30.

Osaseri, G., \& Osamwonyi, I. O. (2019). Impact of stock market development on economic growth in BRICS. International Journal of Financial Research, 10(1), 23-30. https://doi.org/10.5430/ijfr.v10n1p23

Panwar, V., \& Nidugala, G. K. (2019). Impact of budget and GDP annoucements on Indian stock market. Finance India, 33(4), 929-946.

Rehman, I. U., Mahdzan, N. S., \& Zainudin, R. (2016). Is the relationship between macroeconomy and stock market liquidity mutually reinforcing? Evidence from an emerging market. International Journal of Monetary Economics and Finance, 9(3), 294-316. https://doi.org/10.1504/IJMEF.2016.078405

Sabri, N. R. (2009). Causes of high volatility and stock market crises in the developed economies. International Journal of Business and Globalisation, 3(4), 415-434. https://doi.org/10.1504/IJBG.2009.024613

Sengupta, S., Dutta, A., \& Dutta, A. (2019). An empirical study of the effect of macro-economic factors on the stock market: An Indian perspective. Finance India, 33(1), 113-134.

Sharma, G. D., Mahendru, M., \& Singh, S. (2015). Impact of sales, Net Profit, and EPS on stock behavior in emerging markets: A study of Indian companies. Indian Journal of Research in Capital Markets, 2(4), 7-19. https://doi.org/10.17010/ijrcm/2015/v2/i4/102614

Su, C., \& Brookfield, D. (2013). An evaluation of the impact of stock market reforms on IPO under-pricing in China: The certification role of underwriters. International Review of Financial Analysis, 28, 20-33. https://doi.org/10.1016/j.irfa.2013.01.006

Syed, A. M., \& Bajwa, I. A. (2018). Earnings announcements, stock price reaction and market efficiency-the case of Saudi Arabia. International Journal of Islamic and Middle Eastern Finance and Management, 11(3), 416-431. https://doi.org/10.1108/IMEFM-02-2017-0044

Wang, Z., Qian, Y., \& Wang, S. (2018). Dynamic trading volume and stock return relation: Does it hold out of sample?. International Review of Financial Analysis, 58, 195-210. https://doi.org/10.1016/j.irfa.2017.10.003

Weston, J. P. (2000). Competition on the Nasdaq and the impact of recent market reforms. Journal of Finance, 55(6), 2565-2598. https://doi.org/10.1111/0022-1082.00300

\section{Copyrights}

Copyright for this article is retained by the author(s), with first publication rights granted to the journal.

This is an open-access article distributed under the terms and conditions of the Creative Commons Attribution license (http://creativecommons.org/licenses/by/4.0/). 